\title{
Ecological and Social Dimensions of Ecosystem Restoration in the Nordic Countries
}

\author{
Dagmar Hagen $^{1}$, Kristin Svavarsdottir $^{2}$, Christer Nilsson $^{3}$, Anne K. Tolvanen $^{4,5}$, Karsten Raulund-Rasmussen $^{6}$, Àsa L. $^{\text {A }}$ \\ Aradottir $^{7}$, Anna Maria Fosaa ${ }^{8}$ and Gudmundur Halldorsson ${ }^{2}$
}

\begin{abstract}
An international overview of the extent and type of ecological restoration can offer new perspectives for understanding, planning, and implementation. The Nordic countries, with a great range of natural conditions but historically similar social and political structures, provide an opportunity to compare restoration approaches and efforts across borders. The aim of this study was to explore variation in ecological restoration using the Nordic countries as an example. We used recent national assessments and expert evaluations of ecological restoration. Restoration efforts differed among countries: forest and peatland restoration was most common in Finland, freshwater restoration was most common in Sweden, restoration of natural heathlands and grasslands was most common in Iceland, restoration of natural and semi-cultural heathlands was most common in Norway, and restoration of cultural ecosystems, mainly abandoned agricultural land, was most common in Denmark. Ecological restoration currently does not occur on the Faroe Islands. Economic incentives influence ecological restoration and depend on laws and policies in each country. Our analyses suggest that habitat types determine the methods of ecological restoration, whereas socio-economic drivers are more important for the decisions concerning the timing and location of restoration. To improve the understanding, planning, and implementation of ecological restoration, we advocate increased cooperation and knowledge sharing across disciplines and among countries, both in the Nordic countries and internationally. An obvious advantage of such cooperation is that a wider range of experiences from different habitats and different socio-economic conditions becomes available and thus provides a more solid basis for developing practical solutions for restoration methods and policies.
\end{abstract}

Key Words: economic incentives; habitats; land use pressure; northern Europe; regional scale; restoration efforts

\section{INTRODUCTION}

Ecological restoration has become an important practice for counteracting ecosystem degradation, improving ecosystem services and biodiversity, and mitigating global climate change (e.g., MEA 2005, Bullock et al. 2011, Hobbs et al. 2011). Ecological restoration projects vary with regard to objectives, designs, and stakeholders, and relate differently to geographical, political, and historical factors. They also range in scale, methods, and level of intervention (Hobbs and Cramer 2008). Ecological restoration can be motivated by a number of factors, including a need for increased areas for fodder or fuel, or for the provision of other ecosystem services, such as clean water or climate change mitigation; for biodiversity conservation; or simply for counteracting land degradation (for example, Hobbs and Norton 1996, Clewell and Aronson 2006, Suding 2011). A number of financial and nonfinancial mechanisms can also drive ecological restoration, including financial incentives by national or regional governments (de Groot et al. 2007), law and policies, and voluntary work by locals or nongovernmental organizations (NGOs) (McGhee et al. 2007).

The many and varied restoration projects that have been undertaken during the last few decades provide an opportunity to analyze how different geographical, political, historical, and ecological factors influence ecological restoration and its implementation. We present such an analysis, using the Nordic countries as an example. The Nordic countries show many similarities in terms of social, political, and historical backgrounds. They provide a range of habitats with various degrees of abandonment, land use pressure, and degradation, which pose a variety of challenges to restoration. Furthermore, the Nordic countries simultaneously provide several ecosystem services that are important on an international scale, such as carbon sequestration, recreation, and biodiversity.

A multidisciplinary network of scientists, practitioners, policy-makers, and entrepreneurs was established in 2009 in order to improve Nordic collaboration and compile an overview of ongoing ecological restoration activities (Halldórsson et al. 2012). The overview, together with additional information from scientific publications, reports, websites, and expert judgment, was used to analyze ecological restoration in the Nordic countries in order to answer the following questions: (1) Do ecological restoration efforts reflect the level of degradation and land use pressure? (2) How do restoration activities vary among habitats? (3) How do drivers like policy, legislation, and economy influence ecological restoration?

\footnotetext{
${ }^{1}$ Norwegian Institute for Nature Research, ${ }^{2}$ Soil Conservation Service of Iceland, ${ }^{3}$ Landscape Ecology Group, Department of Ecology and Environmental Science, Umeå University, ${ }^{4}$ Finnish Forest Research Institute, Oulu Unit, ${ }^{5}$ Thule Institute, University of Oulu, ${ }^{6}$ Department of Geosciences and Natural Resource Management, University of Copenhagen, ${ }^{7}$ Faculty of Environmental Sciences, Agricultural University of Iceland, ${ }^{8}$ Faroese Museum of Natural History
} 
Fig. 1. The study area includes Denmark, the Faroe Islands, Finland, Iceland, Norway, and Sweden. The figure shows the distribution of the main vegetation zones illustrating the variation in physical conditions within the region. Based on data from Tuhkanen (1987), Moen (1999), and B. Traustason and T. H. Jónsson (unpublished data for Iceland).
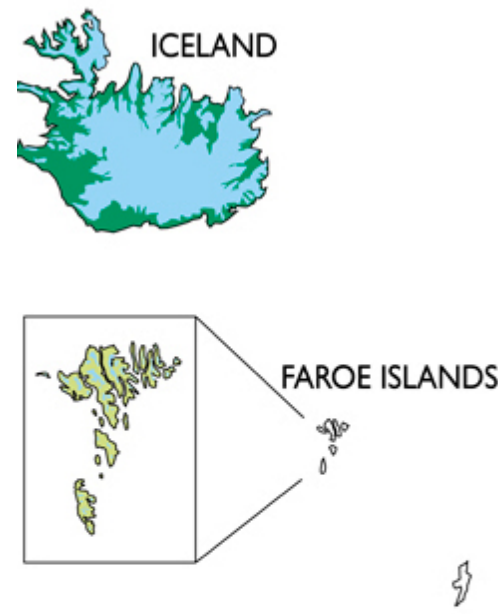

Arctic zone Alpine zones Northern boreal zone Middle boreal zone Southern boreal zone Boreonemoral zone Nemoral zone

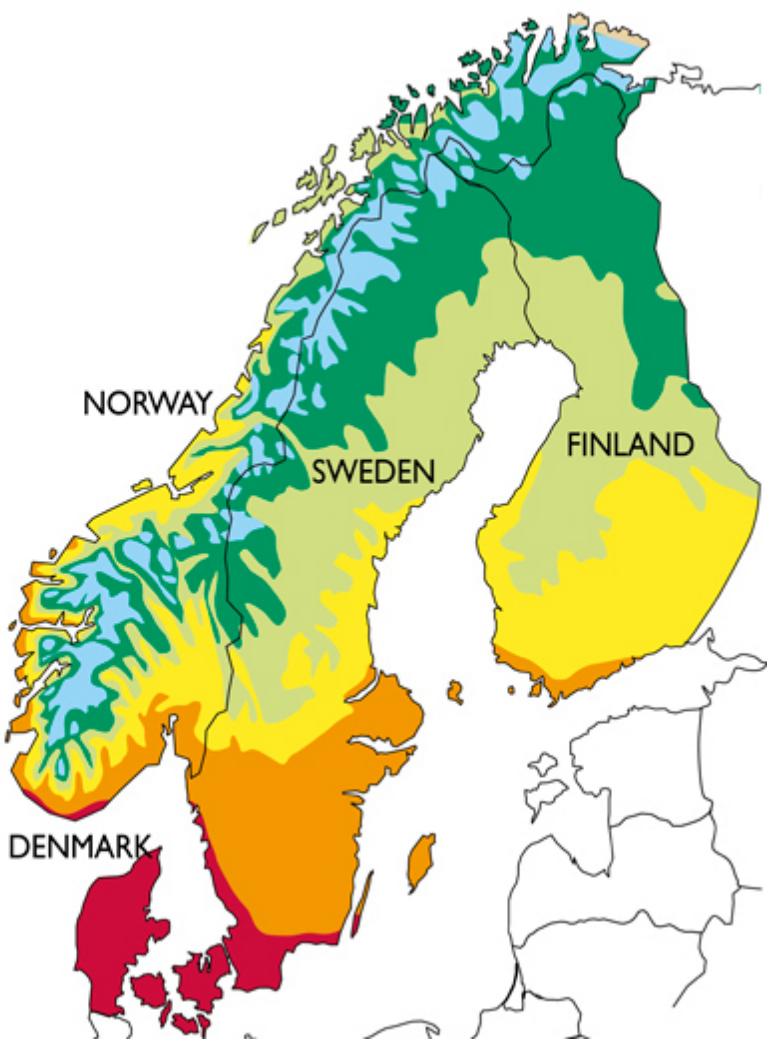

We start by describing for each Nordic country the land use conditions, together with historical and present ecological restoration; we then discuss the similarities and dissimilarities among countries, and finally, put our conclusions in a broader perspective.

\section{THE NORDIC COUNTRIES}

\section{Geography and land use history}

The Nordic countries are located on the northern European mainland and in the North Atlantic between $54^{\circ}$ and $71^{\circ} \mathrm{N}$ and $24^{\circ} \mathrm{W}$ and $30^{\circ}$ E. Five countries (Denmark, Finland, Iceland, Norway, and Sweden) and one associated territory (Faroe Islands) were included in this study (Fig. 1), but we refer to them all as countries. The Nordic countries cover approximately 1.3 million $\mathrm{km}^{2}$ or about $13 \%$ of the land area in Europe (Table 1), and include Europe's northernmost (Norway) and westernmost (Iceland) countries. All except Denmark and the Faroe Islands reach the Arctic Circle. The Nordic countries encompass a range of environmental conditions. Five vegetation zones are present-arctic, alpine, boreal, boreonemoral, and nemoral — of which, the boreal zone is the largest (Fig. 1) (Tuhkanen 1987, Moen 1999). All countries have undergone various degrees of ecosystem degradation, such as deforestation, wetland drainage, river channelization and fragmentation, overgrazing of heathland, urbanization and construction works, and introduction of exotic species (Halldórsson et al. 2012). They also share a common history and have similar societal and cultural traits. All countries are members of the Nordic Council; Denmark, Finland, and Sweden belong to the European Union (EU); and Iceland and Norway are part of the European Economic Area, and ratify legislation similar to that of the EU in many fields, including the environment.

Agriculture has influenced all countries for millennia, and modern forestry has influenced most of them for centuries, but the type and intensity of these land uses have changed in recent decades. Traditional cultural landscapes, such as pastures, rangelands, and streams used for timber floating have been abandoned, and the associated ecosystems are changing because of various successional and recovery processes 
Table 1. Geographic and land cover information for the six Nordic countries (see also Fig. 1). Definitions and descriptions of the land cover types are not completely congruent in the different national statistics.

\begin{tabular}{|c|c|c|c|c|c|c|}
\hline & Denmark $^{1}$ & $\begin{array}{l}\text { Faroe }^{2} \\
\text { Islands }\end{array}$ & Finland $^{3}$ & Iceland $^{4}$ & Norway $\dagger^{5}$ & Sweden $^{6}$ \\
\hline Area $\left(\mathrm{km}^{2}\right)$ & 43,094 & 1393 & 338,424 & 103,000 & 324,300 & 450,295 \\
\hline Population density & 127 & 35 & 17 & 3 & 15 & 21 \\
\hline $\begin{array}{l}\text { Highest altitude (meters above sea } \\
\text { level) }\end{array}$ & 171 & 882 & 1324 & 2110 & 2469 & 2097 \\
\hline \multicolumn{7}{|l|}{ Land cover $\%$} \\
\hline Forest & 14 & $<1$ & 45 & 1 & 38 & 53 \\
\hline Wetland/peatland & 5 & 1 & 26 & 6 & 6 & 9 \\
\hline Heath and natural grassland & 3 & 78 & 4 & 31 & $46 \ddagger$ & 7 \\
\hline Freshwater system & 2 & 1 & 10 & 2 & 7 & 9 \\
\hline Agricultural land & 66 & 8 & 8 & 2 & 3 & 8 \\
\hline Built up land & 10 & & 5 & & 1 & 3 \\
\hline Barren land & & 12 & 2 & 29 & 7 & 12 \\
\hline \multicolumn{3}{|c|}{$\begin{array}{l}\text { T Svalbard not included } \\
{ }^{1} \mathrm{http://www.dst.dk/} \\
{ }^{3} \text { Finnish Statistical Yearbook of Forestry } 2011 \\
{ }^{5} \text { http://www.statkart.no/ }\end{array}$} & \multicolumn{4}{|c|}{$\begin{array}{l}+ \text { Including low-alpine heaths } \\
{ }^{2} \text { Fosaa et al. } 2006 \\
{ }^{4} \text { Hallsdóttir et al. } 2012 \\
{ }^{6} \text { http://www.scb.se/statistik/_publikationer/ } \\
\text { MI0803 2005A01 BR MI03BR0801.pdf }\end{array}$} \\
\hline
\end{tabular}

(Olsson et al. 2000, Nilsson et al. 2005). Land use pressures related to construction, road building, energy development, tourism, and the mining industry are increasing and cause stress on natural environments on small and large scales (Nilsson et al. 2010). Alien species transform ecosystems, including intentionally introduced species, e.g., in forestry (Larsen 1995, Øyen 1999, Gederaas et al. 2012) and reclamation (Magnusson 2010).

The Nordic countries have a long tradition of cooperation on various environmental issues (e.g., Nordic Council of Ministers 2008). They currently put an increasing emphasis on restoring ecosystems affected by degradation. Although ecological restoration activities in the region have increased in recent decades, some efforts date back more than a century (Magnússon 1997, Crofts 2011) but have, over time, been described using various terms. Until recently, there has been very limited cooperation on ecological restoration issues in the region (Halldorsson et al. 2012).

\section{Land use pressure and ecological restoration}

\section{Denmark}

The potential vegetation in Denmark is mixed nemoral deciduous forest dominated by beech (Fagus sylvatica). Today, only a few minor forest remnants without intensive management are left. Most forests are intensively managed either by the use of non-native species, such as Norway spruce (Picea abies) in even-aged monocultures, or as strongly homogenized broad-leaved stands (Nord-Larsen et al. 2010). Most of the land area is managed for agriculture, including high livestock density and the intensive use of fertilizers and pesticides, which results in severe eutrophication and pollution of freshwater and shallow marine waters (Nørring and Jørgensen 2009, Nielsen et al. 2012). Furthermore, ecosystems such as riparian zones, shallow lakes, and wet meadows have been drained, and streams and rivers have been channelized to maximize land for agriculture.

Restoration activities in Denmark are related to both abandoned agricultural land and forests, whereas the rehabilitation of rivers and lakes frequently aims at mitigating significant eutrophication and improving habitats for valued biodiversity (Table 2) (Morsing et al. 2013). Forest restoration includes setting aside natural forests without management, and more frequently, conversion to more nature-friendly management practices (Larsen 2012). The largest restoration project in Denmark is the restoration of the Skjern River (Pedersen et al. 2007). Its main purpose is to restore natural nitrogen and phosphorous retention processes and wetland habitats, and to stop ochre mobilization in the reclaimed meadows. Restoration takes place mainly on public land, but there are also large private-driven projects. Projects are financed by the state, EU funds, and private funds (Table 3).

\section{Faroe Islands}

Intensive sheep grazing has changed ecosystems throughout the Faroe Islands, and the risk of landslide hazards is increasing (Fosaa and Simonsen 2011). Peat has played an important role as fuel for the Faroese population, and peat harvesting has changed the soil conditions and landscape locally. Hydropower exploitation has also exerted pressure on the land 
Table 2. Summary of ecological restoration approaches in the Nordic countries after habitats. The table describes the current best available knowledge and was compiled using national reports and databases, together with other published data.

\begin{tabular}{|c|c|c|c|c|c|c|}
\hline Countries & Forest & Wetland/peatland & Freshwater system & $\begin{array}{c}\text { Heathland/natural } \\
\text { grassland }\end{array}$ & Cultural & Key references \\
\hline Denmark & $\begin{array}{l}\text { Intensive activities, } \\
\text { including set-aside } \\
\text { unmanaged forests and } \\
\text { conversion of } \\
\text { plantation to more } \\
\text { nature like structures; } \\
\text { also restoration of } \\
\text { formerly artificial } \\
\text { drained land }\end{array}$ & $\begin{array}{l}\text { Intensive activities } \\
\text { restoring and } \\
\text { rehabilitating raised } \\
\text { bogs, meadows, and } \\
\text { riparian zones; } \\
\text { management by } \\
\text { controlled grazing in } \\
\text { order to avoid } \\
\text { overgrowing by trees }\end{array}$ & $\begin{array}{l}\text { Rivers and lakes are } \\
\text { intensively restored } \\
\text { and managed for } \\
\text { conservation; } \\
\text { biomanipulation and P- } \\
\text { precipitation in lakes } \\
\text { are tools often used to } \\
\text { mitigate } \\
\text { eutrophication; rivers } \\
\text { are restored to re- } \\
\text { meander }\end{array}$ & $\begin{array}{l}\text { Intensive } \\
\text { management of } \\
\text { cultural heathlands } \\
\text { in order to avoid } \\
\text { overgrowing and to } \\
\text { conserve } \\
\text { characteristic } \\
\text { habitats and species }\end{array}$ & $\begin{array}{l}\text { Marginal lands, } \\
\text { often reclaimed } \\
\text { wetlands, are being } \\
\text { restored; } \\
\text { afforestation taking } \\
\text { place to protect } \\
\text { groundwater and for } \\
\text { recreational } \\
\text { purposes }\end{array}$ & $\begin{array}{l}\text { Larsen and Nielsen } \\
\text { 2007, Jeppesen et al. } \\
\text { 2007, Baastrup-Petersen } \\
\text { 2011, Kristensen et al. } \\
\text { 2011 }\end{array}$ \\
\hline Finland & $\begin{array}{l}\text { Many large-scale } \\
\text { projects aiming at } \\
\text { returning the elements } \\
\text { of pristine forests } \\
\text { through disturbances, } \\
\text { which trigger natural } \\
\text { succession }\end{array}$ & $\begin{array}{l}\text { Many large-scale } \\
\text { projects aiming at } \\
\text { returning peatland } \\
\text { processes and } \\
\text { vegetation succession } \\
\text { through raising the } \\
\text { water table }\end{array}$ & $\begin{array}{l}\text { Hundreds of projects } \\
\text { varying in size aiming } \\
\text { at returning the biota } \\
\text { through manipulations } \\
\text { of stream structure and } \\
\text { improvement of } \\
\text { chemical conditions }\end{array}$ & $\begin{array}{l}\text { Some single } \\
\text { projects aiming at } \\
\text { fixing deteriorated } \\
\text { sites and worn trails } \\
\text { in tourist areas }\end{array}$ & $\begin{array}{l}\text { Hundreds of small } \\
\text { projects aiming at } \\
\text { keeping the } \\
\text { landscape open } \\
\text { through grazing and } \\
\text { mowing, which } \\
\text { prevents natural } \\
\text { succession }\end{array}$ & $\begin{array}{l}\text { Raatikainen } 2009 \text {, } \\
\text { Similä and Junninen } \\
\text { 2011, Finnish Water } \\
\text { Restoration Strategy } \\
\text { Group 2012, Aapala et } \\
\text { al. } 2013\end{array}$ \\
\hline Iceland & $\begin{array}{l}\text { One large and many } \\
\text { small projects aiming } \\
\text { at triggering } \\
\text { successional processes; } \\
\text { native birch and } \\
\text { willows are sometimes } \\
\text { planted in clusters for } \\
\text { establishing seed } \\
\text { source }\end{array}$ & $\begin{array}{l}\text { Few small projects } \\
\text { aiming at restoring } \\
\text { wetland function and } \\
\text { structure by raising } \\
\text { the water table }\end{array}$ & $\begin{array}{l}\text { Few small scattered } \\
\text { projects aiming at } \\
\text { returning the biota } \\
\text { through manipulation } \\
\text { of abiotic factors }\end{array}$ & $\begin{array}{l}\text { Numerous projects } \\
\text { of various size } \\
\text { aiming at } \\
\text { accelerating and } \\
\text { manipulating } \\
\text { succession }\end{array}$ & None & $\begin{array}{l}\text { Aradottir and } \\
\text { Halldorsson } 2011, \\
\text { Aradottir et al. } 2013\end{array}$ \\
\hline Norway & No regular activity & $\begin{array}{l}\text { Some single projects, } \\
\text { often aiming at } \\
\text { restoring habitats for } \\
\text { birds or amphibians }\end{array}$ & $\begin{array}{l}\text { Liming program and } \\
\text { other mitigation efforts } \\
\text { mostly aiming at } \\
\text { improving condition } \\
\text { for anadromous fish }\end{array}$ & $\begin{array}{l}\text { A number of small } \\
\text { and a few larger } \\
\text { projects, mainly in } \\
\text { low-alpine heath } \\
\text { aiming at restoring a } \\
\text { plant cover in } \\
\text { severely disturbed } \\
\text { sites }\end{array}$ & $\begin{array}{l}\text { Many management } \\
\text { initiatives on } \\
\text { abandoned land } \\
\text { aiming at keeping } \\
\text { the landscape open } \\
\text { by removing shrubs } \\
\text { and reintroduce } \\
\text { grazing and mowing }\end{array}$ & $\begin{array}{l}\text { Moen 1999, Navrud } \\
\text { 2001, Sverdrup- } \\
\text { Thygeson and Birkemoe } \\
\text { 2009, Hagen and } \\
\text { Skrindo } 2010\end{array}$ \\
\hline Sweden & $\begin{array}{l}\text { Scattered activities to } \\
\text { restore structural and } \\
\text { functional } \\
\text { heterogeneity; some } \\
\text { projects expand areas } \\
\text { of deciduous forest by } \\
\text { removing conifers to } \\
\text { support rare species }\end{array}$ & $\begin{array}{l}\text { Many projects restore } \\
\text { drained wetlands by } \\
\text { blocking ditches and } \\
\text { restoring former } \\
\text { water tables }\end{array}$ & $\begin{array}{l}\text { Numerous projects } \\
\text { return boulders to river } \\
\text { channels used for } \\
\text { timber floating; others } \\
\text { increase nutrient } \\
\text { retention to reduce } \\
\text { leakage }\end{array}$ & $\begin{array}{l}\text { Many activities to } \\
\text { restore cultural } \\
\text { openness by } \\
\text { removing shrubs } \\
\text { and trees }\end{array}$ & $\begin{array}{l}\text { Many small and at } \\
\text { least one large } \\
\text { project aimed at } \\
\text { restoring e.g., old } \\
\text { pastureland by } \\
\text { removing shrubs } \\
\text { and reintroduce } \\
\text { grazing and mowing }\end{array}$ & $\begin{array}{l}\text { Lindborg and Eriksson } \\
\text { 2004, Lilja et al. 2005, } \\
\text { Jansson et al. 2007, } \\
\text { Malson et al. 2008, } \\
\text { Gardeström et al. } 2013\end{array}$ \\
\hline
\end{tabular}

and on streams. Currently, no ecological restoration projects are carried out in the Faroe Islands (Fosaa and Simonsen 2011).

\section{Finland}

Intensive forest management and energy production are the main land use pressures creating needs for restoration in Finland. Forestry has led to the fragmentation and deterioration of forests and peatlands, and the destruction of the most fertile peatlands. The lack of decomposing wood and burned areas, resulting from forest management, threatens forest biodiversity. In peatlands, draining and peat harvesting cause the greatest risks to biodiversity (Rassi et al. 2010).
Freshwater systems are impacted mainly by hydroelectric development and heavy nutrient runoff from construction, forestry, and agricultural areas (Rassi et al. 2010).

Restoration efforts in Finland are directed principally at forests and peatlands located in protected areas, and in overgrowing cultural habitats either on protected or unprotected land with valuable landscapes (Table 2). Restoration of freshwater ecosystems is also active but can be problematic where neighboring areas continue to cause nutrient loading. Freshwater habitats are, however, usually not restored if this compromises energy production. Most previously harvested 
Table 3. General outline of societal factors relevant to restoration activities in the Nordic countries, with focus on the main elements within each factor. The Faroe Islands are not included because there is no current restoration activity. The table describes the current best available knowledge and was compiled using national reports and databases, together with other published data.

\begin{tabular}{|c|c|c|c|c|}
\hline Country & Initiators/actors & Main drivers & Land tenure & Economy \\
\hline Denmark & $\begin{array}{l}\text { National authorities, } \\
\text { municipalities, private funds, } \\
\text { nongovernmental organizations } \\
\text { (NGOs) }\end{array}$ & $\begin{array}{l}\text { National policy on nature protection, } \\
\text { including biodiversity, habitat, and water } \\
\text { framework directives }\end{array}$ & $\begin{array}{l}\text { Mainly on state-owned land, but } \\
\text { also some large projects on private } \\
\text { land }\end{array}$ & $\begin{array}{l}\text { Mixture of national, } \\
\text { European Union } \\
\text { (EU), and private } \\
\text { funds }\end{array}$ \\
\hline Finland & $\begin{array}{l}\text { Both state and local authorities, } \\
\text { such as the Metsähallitus, and } \\
\text { NGOs }\end{array}$ & $\begin{array}{l}\text { National policies on the environment } \\
\text { (forestry, water protection, pollution } \\
\text { control and control of non-native species). } \\
\text { EU Habitat Directive and EU Water } \\
\text { Framework Directive }\end{array}$ & Mainly on state-owned land & $\begin{array}{l}\text { Mixture of national } \\
\text { and EU funds }\end{array}$ \\
\hline Iceland & $\begin{array}{l}\text { Soil Conservation Service, } \\
\text { energy companies, local } \\
\text { landowners, and NGOs }\end{array}$ & $\begin{array}{l}\text { Extensive soil erosion and volcanic } \\
\text { activity; governmental policies, partly } \\
\text { stimulated by the United Nations } \\
\text { conventions on climate change and } \\
\text { biodiversity }\end{array}$ & $\begin{array}{l}\text { Mixture of state-owned and } \\
\text { private land }\end{array}$ & $\begin{array}{l}\text { Mainly national } \\
\text { funds, but some from } \\
\text { industry (mainly } \\
\text { energy companies) }\end{array}$ \\
\hline Norway & $\begin{array}{l}\text { State and local authorities, and } \\
\text { stakeholders within hydropower } \\
\text { and other infrastructure } \\
\text { development }\end{array}$ & $\begin{array}{l}\text { Governmental policies, legacy like the } \\
\text { Nature Diversity Act, EU Water } \\
\text { Framework Directive }\end{array}$ & $\begin{array}{l}\text { Mainly on state-owned land and } \\
\text { common properties, some small } \\
\text { scale projects on private land }\end{array}$ & $\begin{array}{l}\text { National funds or the } \\
\text { industry (like energy } \\
\text { companies) }\end{array}$ \\
\hline Sweden & $\begin{array}{l}\text { State and local authorities, such } \\
\text { as National Board of Forestry, } \\
\text { municipalities, and NGOs }\end{array}$ & $\begin{array}{l}\text { National policies on the environment (on } \\
\text { forestry, water protection, pollution } \\
\text { control and control of non-native species); } \\
\text { EU Habitat Directive and EU Water } \\
\text { Framework Directive }\end{array}$ & Mainly on state-owned land & $\begin{array}{l}\text { Mixture of national } \\
\text { and EU funds }\end{array}$ \\
\hline
\end{tabular}

peatlands have not been restored but instead have been afforested. Both state and local authorities are involved in restoration, and EU LIFE funding is crucial for large-scale projects (Table 3). The largest restoration project in Finland currently is Boreal Peatland Life, and it aims at restoring nearly $43 \mathrm{~km}^{2}$ of various kinds of peatlands in 54 Natura 2000 protection areas around Finland.

\section{Iceland}

Agriculture, forestry, and infrastructure development are the major land use pressures in Iceland. The onset of anthropogenic influences following the settlement of Iceland in the ninth century, combined with a harsh climate, volcanic soils, and fragile ecosystems, led to catastrophic ecosystem degradation and soil erosion, and the loss of more than 95\% of native birch woodlands (Aradottir and Arnalds 2001, Arnalds et al. 2001, Gisladóttir et al. 2010). During the 20th century, more than half of the natural wetlands in Iceland's lowland areas were drained for agricultural purposes (Óskarsson 1998), and the woodland remnants were further fragmented by the planting of exotic trees (Blöndal and Gunnarsson 1999). Reservoirs associated with hydropower plants have disturbed many catchments, and power lines are widespread (Arnalds and Aradóttir 2011). Furthermore, the use of invasive exotic species in revegetation activities and forestry poses a risk to native ecosystems (Magnusson 2010).

Most restoration activities in Iceland involve revegetation of eroded land, which most often results in the restoration of grasslands, heathlands, or woodlands (Table 2). Some wetland restoration occurs but is limited compared to the extensive drainage of wetlands (Aradóttir and Halldórsson 2011). Most ecological restoration has been initiated by state agencies, especially the Soil Conservation Service of Iceland, but energy companies, local landowners, and NGOs have also been important actors in restoration (Table 3). The current largest ecological restoration project in Iceland is the Hekluskogar project, which covers approximately $900 \mathrm{~km}^{2}$ (nearly $1 \%$ of Iceland); it aims at restoring the native birch woodland and shrubland around the volcano Mt. Hekla (Aradottir 2007).

\section{Norway}

Forestry and ecological changes in abandoned land are striking land use features in Norway, but the loss of wilderness, and land use conflicts related to hydropower and other infrastructure developments are becoming more prominent (Taugbøl et al. 2001, Bryn et al. 2013, Directorate for Nature Management 2012, Statistics Norway 2012). Non-native species are present in all habitats, and some of them have negative effects on biodiversity, like modifying rare nature types and suppressing native species (Gederaas et al. 2012).

Until the last two decades, reclamation activities in Norway were restricted to practical measures such as seeding spoil heaps and roadsides (Hagen and Skrindo 2010, Rydgren et al. 2011). There is, however, a growing interest in ecological restoration in different habitats (Table 2), and close cooperation between management authorities, public 
agencies, scientists, and practitioners is often the situation for Norwegian restoration activities (Hagen and Skrindo 2010). Most projects are small and not part of any larger policy or strategic plan, but new legislation acknowledges the use of ecological restoration in nature management (Table 3). The current largest ecological restoration project in Norway is the restoration of a mountain military training area (Martinsen and Hagen 2010, Hagen and Evju 2013).

\section{Sweden}

The current main land use pressures in Sweden include forestry, agriculture, and energy production. Restoration efforts are directed primarily at ecosystems where prevailing land use types have been abandoned, and to ecosystems where current land use causes side effects that threaten other systems. In the former category, major restoration efforts are directed at free-flowing rivers that were previously channelized for timber floating, at drained wetlands with poor wood production, and at overgrowing pastures (Table 2). The second category includes projects such as the Kävlinge River project, where the river catchment has been filled with small retention impoundments to reduce nutrient leakage into areas downstream (Lindahl and Söderqvist 2004). In intensively used systems, such as production forests and hydroelectric rivers, restoration is restricted because of the difficulties in combining production with restoration measures. Forest landscapes include examples of restoration activities to reintroduce functional and structural heterogeneity, in some cases triggered by attempts to support populations of threatened species, such as the White-backed Woodpecker (Dendrocopos leucotos) (Roberge et al. 2008). In hydroelectric rivers, facilitation of fish migration is a major concern, although there are few real-world examples. The restoration activities in Sweden are funded both by state and private bodies, and EU funding has made it possible to also accomplish very large projects (Table 3 ).

\section{ECOLOGICAL RESTORATION AMONG COUNTRIES}

\section{Land use pressure as a driver for ecological restoration}

The large variation in environmental conditions among the Nordic countries explains most of the differences in land use history within the region, and contributes to differences in the type and extent of restoration. Denmark has fertile soils and the most favorable climate for agriculture, and its physical geography is comparable with neighboring Central European countries. On the other hand, Iceland's harsh climate and volcanism cause vulnerable ecological conditions that are unique in Europe. The variation in population density is concurrent with this geographic gradient, ranging from three inhabitants per square kilometer in Iceland to 127 in Denmark (Table 1).

In all countries, the main land use pressure is related to the dominant habitats. Boreal forests dominate Finland and
Sweden, and the highest land use pressures in both countries are related to forestry, which affects forests, peatlands, and rivers. This is reflected in the ongoing restoration efforts in Finland, where restoration of forests and peatlands is emphasized. Streams and rivers and other freshwater systems receive the most restoration efforts in Sweden, and this focus relates to changes in the forestry industry, as the transition from timber floating to timber transport by trucks made rivers and streams that were not developed for hydropower available for restoration (Nilsson et al. 2005). Heathland and grassland are currently the dominant habitat types in Iceland, where most of the forests have been destroyed. The highest land use pressure comes from overgrazing, which, in combination with geographic factors, has resulted in extensive deserted areas (Arnalds et al. 2001). Thus, the efforts and scale of ecological restoration of eroded land in Iceland have been larger than in any other Nordic country, more in line with the scale and strategies of restoration in the North American prairies and the Australian grasslands (Prober et al. 2005, Mabry et al. 2010). Norway falls between the other countries, with a large range of habitat types, intermediate land use pressures, and emerging, but limited, restoration activity within most habitats. Low population density and remote wilderness areas have partly diminished land use pressure in Norway, although technological and economic developments are currently putting pressure on all habitats, thus increasing the need for ecological restoration (Hagen and Skrindo 2010). In contrast, all habitats in Denmark have a strong cultural component. This is reflected in the restoration activities that focus on land formerly used for agriculture (Table 2), which has much in common with ongoing restoration activities in the Netherlands, UK, and Germany (Madgwick and Jones 2002).

Restoration activities in some habitat types are limited despite high land use pressures and degradation. For example, wetland restoration has had low priority in Iceland, despite high pressure on this habitat type in the latter part of the 20th century (Halldórsson et al. 2011, Hallsdóttir et al. 2012). Likewise, no restoration is carried out in heathland or grassland habitats in the Faroe Islands, even though overgrazing is the most intense land use pressure causing degradation of these habitats (Fosaa and Simonsen 2011). This indicates that factors other than land use pressure influence how much effort is put into restoration in the Nordic countries.

\section{Habitat restoration}

Ecological restoration projects in the Nordic countries vary both in context and activities due to variation in ecological conditions, vegetation zones, ecosystem pressures, and population densities. In spite of this, restoration activities within specific habitats, such as forests and wetlands, are relatively similar across the region (Table 2).

Forest restoration, independent of the pressure and the level of forest destruction in different countries, appears to be done with an aim of influencing the direction and speed of 
succession (sensu Walker and del Moral 2003). Commercial forestry has degraded and fragmented the boreal forests in Finland, Norway, and Sweden, but most of their structure and dynamics might eventually recover, given enough time. Restoration speeds up natural succession in terrestrial habitats (e.g., Walker and del Moral 2009), and natural disturbances in forests are imitated by using controlled fire, small clearings, storm simulation, and tree damage, which trigger the successional trajectories (Kuuluvainen et al. 2002). Planting of introduced species has strongly influenced significant parts of Denmark's forest ecosystems (Larsen 2012), which has made the reintroduction of native species, such as beech, an essential restoration component. The same reasoning applies to degraded woodlands in Iceland that are below the threshold for natural recovery (Aradottir and Eysteinsson 2005). There, birch (Betula pubescens) and native willows (e.g., Salix phylicifolia and S. lanata) are reintroduced by planting or seeding, preceded by reclamation for surface stabilization when required (Aradottir and Eysteinsson 2005, Oskarsson et al. 2006, Aradottir 2007), which promotes transition between successional stages, and faster recovery.

Restoration of wetland and freshwater habitats is conducted primarily by restoring the physical and chemical structure, and allowing organisms to colonize later (Table 2). Wetland restoration relies on recreating the hydrological regime in its predisturbance state to aid the recovery of attributes such as decomposition rate, peat reformation, and species assemblages (e.g., Laine et al. 2011). The EU Water Framework Directive, which pushes for good ecological and chemical status in surface waters (Heiskanen et al. 2004), makes restoration of abiotic conditions a primary task (Jungwirth et al. 2002).

Strategies for restoring heathland and grassland vary among countries more than for any other habitat. This variability can partly be explained by the diverse environmental conditions of heathland, which range from arctic-alpine heath vegetation in northern and mountain areas of Norway, Sweden, and Finland to lowland cultural heathland in Denmark and the west coast of Norway. Seeding, planting, and fertilizing are used to accelerate the succession of degraded heathland and grassland communities in Finland, Norway, and Iceland (Gretarsdóttir et al. 2004, Hagen and Evju 2013). In Norway, there are examples of heathland restoration without the addition of plants or seeds, such as the removal of roads and other infrastructures, and the restoration of physical conditions in the landscape (e.g., Martinsen and Hagen 2010).

Similarities in the environmental constraints and rates at which certain habitat types can regenerate within these northern habitats may explain why the same methods or techniques were applied in certain habitats, regardless of country. Alternative explanations could be that habitats have historically been used in similar ways and thus provide common challenges for restoration across countries, or that only limited restoration tools are available for a given habitat. Similarities within habitats, independent of country, indicate that the restoration strategy is driven by the type of ecosystem or habitat that is being restored.

\section{Restoration of natural vs. cultural habitats}

An important aspect that varies among the Nordic countries is the proportion of "natural" vs. cultural habitats. While Denmark has a large proportion of cultural habitats characterized by intensive management, other areas, especially the northern parts of Finland, Norway, and Sweden, have extensive nearly pristine land. These circumstances clearly affect the aim and design of ecological restoration. Where the current land use pressure is low and habitats are nearly natural, restoration can strive toward reaching a natural state. In areas with a long cultural history, on the other hand, such targets are usually unrealistic and not even considered. Natural successional trajectories are generally not accepted in cultural landscapes, and ecological restoration requires continuous management to maintain their values. Thus, restoration often has the objective of recreating former cultural states that have desirable values. Such restoration often requires continuous management to favor specific biodiversity, as in the restoration of grasslands that are grazed or scythed. In the Nordic countries, the most notable examples are the Danish and Norwegian cultural heathlands, which are maintained as a part of cultural heritage by regular management, including burning, mowing, grazing, and removal of colonizing trees (Webb 1998, Norderhaug and Johansen 2011).

\section{Policy, legislation, and economy behind ecological restoration}

Technological and economic developments have caused large changes in societies and land use. Opportunities for ecological restoration have arisen following the availability of previously occupied land due to farmland abandonment or reduced emphasis on traditional farming activities (e.g., Aradottir and Eysteinsson 2005, Madsen et al. 2005), the halting of log floating on rivers (Nilsson et al. 2005), the relocation of military practice ranges (Hagen and Evju 2013), or other land use changes.

The availability of land for ecological restoration seems to be linked to economic development. This can be associated with decreased profitability of former land use in an area, which provides an opportunity for restoration to a more natural state (Bossuyt et al. 2001) or creation of new habitat types (Milgrom 2008). Hydropower production has considerable economic importance, and rivers used for this purpose are usually not available for ecological restoration unless power stations are in need of renovation or if permissions are terminated; in the latter cases, even dam removal can be possible (Lejon et al. 2009, Jørgensen and Renöfält 2013). Similarly, large peatland 
areas were drained in Finland in order to produce timber, but unsatisfactory results have generated discussions about peatland restoration also outside of protected areas (Ministry of Agriculture 2011). Even on heavily degraded land, unsustainable use may be favored over ecological restoration if important stakeholders regard the area as socially or economically important, as is the case for many highland commons of Iceland that are used for sheep grazing (Arnalds and Barkarson 2003). The same applies to intensive agriculture on marginal soils in Denmark, Finland, and Sweden, where the profitability relies on subsidies from the $\mathrm{EU}$ or the governmental subsidies for building timber roads to access forestry in remote areas in Norway (Bruvoll et al. 2011). Various incentives, including monetary ones, are often the most effective drivers of ecological restoration (de Groot et al. 2007, McGhee et al. 2007).

Most of the Nordic countries have laws and policies that encourage restoration, directly or indirectly, such as governmental support to restore prioritized habitats in Denmark http://2.naturerhverv.fvm.dk/natur- og miljoeprojekter. aspx?ID=65019), the Swedish Environmental Objectives (http://www.miljomal.nu/Global/24 las mer/broschyrer/Swedensenvironmental-objectives.pdf), legislation on nature conservation in Finland (Finland's Nature Conservation Act 1996) and Norway (Nature Diversity Act 2009), and legislation on soil conservation in Iceland (Soil Conservation Act 1965). Increased emphasis on ecological restoration in international policies (e.g., Bullock et al. 2011) has influenced national policies in the Nordic countries. In Denmark, Finland, and Sweden, much restoration is made possible by the EU's LIFEfunded restoration projects. This accounts for the wellorganized forest and peatland restoration in Finland, while freshwater restoration in the country has received less EU LIFE funding and comprises numerous small-scale projects that use different strategies (Table 2). In addition, management in order to improve so-called favorable ecological condition rather than strict ecological restoration is also important (Morsing et al. 2013).

New incentives, such as the Aichi targets of the Convention on Biological Diversity's 2011-2020 strategic plan (http:// www.cbd.int/sp/), have the potential to affect national policy and promote restoration activity in the coming years. Carbon sequestration in soils and vegetation as a mitigation action under the United Nations Framework Convention on Climate Change has been one of the drivers of revegetation and reforestation in Iceland since the late 1990s (Arnalds 2004). Recently, it has also been shown to be a driver for wetland restoration (Icelandic Ministry for the Environment 2007). On the other hand, tree plantation programs aimed solely at carbon sequestration may counteract restoration if they rely on exotic species (cf. Lindenmayer et al. 2012). EU policies such as the EU Habitat Directive and EU Water Framework Directive have been drivers of ecological restoration in Denmark, Finland, and Sweden through the LIFE program (e.g., Jones et al. 2007, Silva et al. 2007, Gardeström et al. 2013, Morsing et al. 2013). Norway and Iceland have not approved the EU Habitat Directive and do not participate in the LIFE program, but the EU Water Framework Directive has nevertheless become a driver of river restoration in Norway (http://www. vannportalen.no/).

Most restoration projects in the Nordic countries take place on public and state-owned land (Table 3). Projects on private land tend to be smaller (Aradóttir and Halldórsson 2011), although there are examples of large restoration projects on private land, like the Filsø restoration in Denmark (http:// www.avjf.dk/natur/filso/). Experiences from all the countries indicate that landowners are strongly driven by monetary incentives (METSO 2008, Aradóttir et al. 2013), but other incentives, such as the provision of materials for carrying out the restoration, education, and extension services, are also important drivers (Arnalds 2004, Skarphéðinsson 2011). Monetary incentives can, however, also counteract ecological restoration if they fund actions that compete with ecological restoration (Schuyt 2005). Examples include regional farm afforestation projects in Iceland that emphasize timber production with exotic species (Aradottir and Eysteinsson 2005), and seeding of alpine spoil heaps with commercial seed mixtures in Norway and Sweden (Rydgren et al. 2011).

National and local authorities and agencies strongly influence land use and development processes in all the Nordic countries, and are therefore important actors in restoration. Public presence in ecological restoration is also strong. Farmers, who most often are private landowners, play an important role in ecological restoration in Iceland through the project "Farmers Heal the Land," in which approximately 20\% of the nation's sheep farmers participate (Arnalds 2005, Pétursdóttir 2011). However, the farmers often focus on ecosystem services, such as grazing, prevention of soil erosion, or improved productivity. Private companies or landowners might also promote their own projects based on private involvement or special interests, which in this sense is comparable with engagement from NGOs. As observed in other regions, NGOs have a role in advocating restoration (for example, McGhee et al. 2007), especially in wetlands and freshwater habitats. In a recent example, NGOs bought valuable nature areas in Denmark in order to protect and restore nature values (http://www.danmarksnaturfond.dk/Default. aspx?ID=3821). The involvement of NGOs seems to be stronger in projects with a clear and engaging aim, like saving birds or re-establishing bird habitats, and such projects are often carried out in close cooperation with, or receive monetary support from, public authorities (Martinsen and Vedum 2010). 


\section{THE BROADER PERSPECTIVE: AN INTERNATIONAL APPROACH TO ECOLOGICAL RESTORATION}

With increasing anthropogenic pressures on the world's ecosystems, ecological restoration has become more important than ever. In a recent review, Suding (2011) asks whether the young discipline of restoration ecology is ready for the era of restoration, and emphasizes the need for evaluating the success of restoration projects. Our analysis focused on achieving an overview of the extent, types, and drivers of ecological restoration carried out in the Nordic countries. We have not included an analysis of the outcomes, i.e., successes and failures of restoration projects in the region; however, such analysis is needed, and our study provides a basis for it.

Our international approach offers new perspectives for understanding, planning, and implementing ecological restoration. We have found that differences among countries in factors such as geography, land use, policy, legislation, and economy have fostered differences in the extent and emphasis of ecological restoration. In other words, these differences determine if, when, and where to do restoration. One important finding is that the funding of restoration projects by the EU has given Denmark, Finland, and Sweden new opportunities to increase the impact of restoration compared to the other Nordic countries. LIFE-funded projects have often greater than country-level impacts, as they are evaluated against EU environmental policy objectives. EU-level evaluation increases the quality of the projects, and since a significant share of project funding has to be used for disseminating and communicating project outcomes, experiences and good practice spread over a wide area across and beyond the EU. We have also found that, despite national differences, restoration methods, or how restoration is done, can be analogous, although not necessarily identical, at the habitat level, irrespective of country. These results indicate a combination of both local habitat-specific solutions and international influences.

Many authors have emphasized the need for international cooperation in ecological restoration (e.g., Beklioglu et al. 2007, Steffens 2008, Lü et al. 2011). Furthermore, links and increasing communication between scientists across disciplines and practitioners are needed (Eitzel et al. 2012). To improve the regional development of ecological restoration, we advocate for increased cooperation and knowledge sharing across disciplines and among countries, both in the Nordic countries and internationally. An obvious advantage of such cooperation is that information and experiences from a wider range of habitats become available and thus provide a more solid basis for developing practical solutions for restoration methods and policies. The level of intervention required in restoration varies and depends on local conditions and scale (Hobbs and Cramer 2008). At present, handbooks and guidelines on best practice restoration methods are prepared separately in each of the Nordic countries (Table 2). Joint elaboration of project designs and techniques, and evaluation of restoration outcomes can provide understanding, planning, and implementation of ecological restoration on habitat level across borders.

Socio-economic experiences can also be shared. Crosscomparison of similarities and differences within groups of countries will most likely give new insight into processes and mechanisms of relevance to different stages of policy-making (Baker and Eckerberg 2013). Continuous discussion is needed between scientists, decision-makers, and the general public, on a national and international level, concerning the needs and targets related to land use and restoration. Information on the ecological, social, and economic impacts of land use and the needs for habitat restoration can be used by decision-makers when setting targets and objectives concerning ecological restoration. Joint identification of restoration priorities will be valuable, e.g., a Nordic agenda for ecological restoration aimed at locating restoration efforts to habitats and regions where they are most useful, in terms of ecological as well as social aspects.

Responses to this article can be read online at: http://www.ecologyandsociety.org/issues/responses. php/5891

\section{Acknowledgments:}

This paper is a product of a Nordic network "Restoration of Damaged Ecosystems in the Nordic Countries (ReNo)" funded by the Nordic Council of Ministers during 2009-2011. We thank Kari Sivertsen, Norwegian Institute for Nature Research, for drawing Figure 1, Scott Wilson for reading and commenting on the manuscript, and an anonymous reviewer for valuable comments on a previous version.

\section{LITERATURE CITED}

Aapala, K., M. Similä, and J. Penttinen, editors. 2013. Ojitettujen soiden ennallistamisopas. (Abstract in English: Handbook for the restoration of drained peatlands). Metsähallitus Natural Heritage Services, Series B.

Aradottir, A. L. 2007. Restoration of birch and willow woodland on eroded areas. Pages 67-74 in G. Halldorsson, E. S. Oddsdottir, and O. Eggertsson, editors. Effects of afforestation on ecosystems, landscape and rural development. Reykholt, Iceland, June 18-22, 2005. TemaNord 2007:508. [online] URL: http://eprints.ulster.ac. uk/14798/1/AFFORNORD_Conference.pdf 
Aradottir, A. L., and O. Arnalds. 2001. Ecosystem degradation and restoration of birch woodlands in Iceland. Pages 293-306 in F. E. Wielgolaski, editor. Nordic mountain birch ecosystems. UNESCO, Paris, France.

Aradottir, A. L., and T. Eysteinsson. 2005. Restoration of birch woodlands in Iceland. Pages 195-209 in J. A. Stanturf and P. Madsen, editors. Restoration of boreal and temperate forests. CRC Press, Boca Raton, Florida, USA.

Aradóttir, Á. L., and G. Halldórsson, editors. 2011. Vistheimt á Íslandi [Ecological restoration in Iceland]. Agricultural University of Iceland and Soil Conservation Service of Iceland, Reykjavík, Iceland.

Aradóttir, Á. L., T. Petursdottir, G. Halldorsson, K. Svavarsdottir, and O. Arnalds. 2013. Drivers of ecological restoration: lessons from a century of restoration in Iceland. Ecology and Society 18(4): 33. http://dx.doi.org/10.5751/ ES-05946-180433

Arnalds, A. 2004. Carbon sequestration and the restoration of land health. Climatic Change 65:333-346. http://dx.doi. org/10.1023/B:CLIM.0000038204.60219.0a

Arnalds, A. 2005. Approaches to landcare-a century of soil conservation in Iceland. Land Degradation \& Development 16:113-125. http://dx.doi.org/10.1002/ldr.665

Arnalds, Ó., and Á. L. Aradóttir. 2011. Rask á Íslandi [Disturbances in Iceland]. Pages 19-23 in Á. L. Aradóttir and G. Halldórsson, editors. Vistheimt á Íslandi. Agricultural University of Iceland and Soil Conservation Service of Iceland, Reykjavík, Iceland.

Arnalds, O., and B. H. Barkarson. 2003. Soil erosion and land use policy in Iceland in relation to sheep grazing and government subsidies. Environmental Science \& Policy 6:105-113. http://dx.doi.org/10.1016/S1462-9011(02)00115-6

Arnalds, O., E. F. Thorarinsdottir, S. Metusalemsson, A. Jonsson, E. Gretarsson, and A. Arnason. 2001. Soil erosion in Iceland. Soil Conservation Service and Agriculture Research Institute, Reykjavík, Iceland.

Baker, S., and K. Eckerberg. 2013. A policy analysis perspective on ecological restoration. Ecology and Society 18 (2):17. http://dx.doi.org/10.5751/ES-05476-180217

Beklioglu, M., S. Romo, I. Kagalou, X. Quintana, and E. Bécares. 2007. State of the art in the functioning of shallow Mediterranean lakes: workshop conclusions. Hydrobiologia 584:317-326. http://dx.doi.org/10.1007/s10750-007-0577-x

Blöndal, S., and S. B. Gunnarsson. 1999. Íslandsskógar. Hundrað ára saga [Icelandic forests. History of one hundred years]. Mál og mynd, Iceland.
Bossuyt, B., O. Honnay, K. Van Stichelen, M. Hermy, and J. Van Assche. 2001. The effect of a complex land use history on the restoration possibilities of heathland in central Belgium. Belgian Journal of Botany 134:29-40.

Bruvoll, A., J. M. Skjelvik, and H. Vennemo. 2011. Reforming environmentally harmful subsidies. How to counteract distributional impacts. TemaNord 2011:551. Nordisk ministerråd, København.

Bryn, A., P. Dourojeanni, L. O. Hemsing, and S. O'Donnell. 2013. A high-resolution GIS null model of potential forest expansion following land use changes in Norway. Scandinavian Journal of Forest Research 28:81-98. http://dx. doi.org/10.1080/02827581.2012.689005

Bullock, J. M., J. Aronson, A. C. Newton, R. F. Pywell, and J. M. Rey-Benayas. 2011. Restoration of ecosystem services and biodiversity: conflicts and opportunities. Trends in Ecology \& Evolution 26:541-549. http://dx.doi.org/10.1016/ j.tree.2011.06.011

Clewell, A. F., and J. Aronson. 2006. Motivations for the restoration of ecosystems. Conservation Biology 20:420-428. http://dx.doi.org/10.1111/j.1523-1739.2006.00340.x

Crofts, R. 2011. Healing the land. Soil Conservation Service of Iceland, Gunnarsholt, Iceland.

de Groot, R., M. de Wit, E. J. Brown Gaddis, C. Kousky, W. McGhee, and M. D. Young. 2007. Making restoration work: financial mechanisms. Pages 286-293 in J. Aronson, S. J. Milton, and J. N. Blignaut, editors. Restoring natural capital. Science, business, and practice. Island Press, Washington, D. C., USA.

Directorate for Nature Management. 2012. Inngrepsfrie naturområder i Norge [Areas without major infrastructure in Norway —INON]. http://www.dirnat.no/inon/

Eitzel, M. V., S. Diver, H. Sardinas, L. M. Hallett, J. J. Olson, A. Romero, G. D. T. Oliveira, A. T. Schuknecht, R. Tidmore, and K. N. Suding. 2012. Insights from a cross-disciplinary seminar: 10 pivotal papers for ecological restoration. Restoration Ecology 20:147-152. http://dx.doi.org/10.1111/ j.1526-100X.2011.00840.x

Finnish Statistical Yearbook of Forestry. 2011. Finnish Forest Research Institute, Helsinki, Finland.

Finnish Water Restoration Strategy Group. 2012. Vesien kunnostustyöryhmän loppuraportti. (Water restoration strategy report, in Finnish) [online] URL: http://www. ymparisto.fi/download.asp? contentid $=133956 \& l a n=f i$

Fosaa, A. M., J. Dalsgarð, and E. Gaard, editors. 2006. Føroya Náttúra-Livfrøðiligt margfeldi [The nature of the Faroe 
Islands—biodiversity]. Føroya Skúlabókagrunnur, Torshavn, Faroe Islands.

Fosaa, A. M., and W. Simonsen, editors. 2011. Lendisnýtsla i Foroyum [Land use activities in the Faroe Islands]. Faroese Museum of Natural History, Tórshavn, Faroe Islands.

Gardeström, J., D. Holmqvist, L. Polvi, and C. Nilsson. 2013. Demonstration restoration measures in tributaries of the Vindel River catchment. Ecology and Society 18(3):18. http:// dx.doi.org/10.5751/ES-05609-180308

Gederaas, L., T. I. Moen, S. Skjelseth, and L.-K. Larsen, editors. 2012. Fremmede arter i Norge-med norsk svarteliste 2012 (Alien species in Norway-including Norwegian blacklist 2012). Norwegian Biodiversity Information Centre, Trondheim, Norway.

Gisladottir, G., E. Erlendsson, R. Lal, and J. Bigham. 2010. Erosional effects on terrestrial resources over the last millennium in Reykjanes, southwest Iceland. Quaternary Research 73:20-32. http://dx.doi.org/10.1016/j.yqres.2009.09.007

Gretarsdottir, J., A. L. Aradottir, V. Vandvik, E. Heegaard, and H. J. B. Birks. 2004. Long-term effects of reclamation treatments on plant succession in Iceland. Restoration Ecology 12:268-278. http://dx.doi.org//10.1111/j.1061-2971.2004.00371. $\underline{x}$

Hagen, D., and M. Evju. 2013. Using short-term monitoring data to achieve goals in a large-scale restoration. Ecology and Society 18(3):29. http://dx.doi.org/10.5751/ES-05769-180329

Hagen, D., and A. B. Skrindo, editors. 2010. Restaurering av natur i Norge - et innblikk i fagfeltet, fagmiljфet og pågående aktivitet [Restoration of nature in Norway-a glimpse into the tematic field, professional institutions and ongoing activity]. Norwegian Institute for Nature Research, Trondheim, NINA Temahefte 42 .

Halldórsson, G., Á. L. Aradóttir, Ó. Arnalds, and K. Svavarsdóttir. 2011. Ecological restoration in Iceland. Pages 9-12 in Á. L. Aradóttir and G. Halldórsson, editors. Vistheimt á Íslandi [Ecological restoration in Iceland]. Agricultural University of Iceland and Soil Conservation Service of Iceland, Reykjavík, Iceland.

Halldorsson, G., A. L. Aradottir, A. M. Fosaa, D. Hagen, C. Nilsson, K. Raulund-Rasmussen, A. B. Skrindo, K. Svavarsdóttir, and A. Tolvanen. 2012. Restoration of damaged ecosystems in the Nordic countries. TemaNord 2012:558. Nordic Council of Ministers, Copenhagen, Denmark.

Hallsdóttir, B. S., C. Wöll, J. Guðmundsson, A. Snorrason, and J. Pórsson. 2012. Emissions of greenhouse gases in Iceland from 1990 to 2010. Environment Agency of Iceland, Reykjavík, Iceland.
Heiskanen, A. S., W. van de Bund, A. C. Cardoso, and P. Noges. 2004. Towards good ecological status of surface waters in Europe -interpretation and harmonisation of the concept. Water Science and Technology 49:169-177.

Hobbs, R. J., and V. A. Cramer. 2008. Restoration ecology: interventionist approaches for restoring and maintaining ecosystem function in the face of rapid environmental change. Annual Review of Environment and Resources 33:39-61. http://dx.doi.org/10.1146/annurev.environ.33.020107.113631

Hobbs, R. J., L. M. Hallett, P. R. Ehrlich, and H. A. Mooney. 2011. Intervention ecology: applying ecological science in the twenty-first century. Bioscience 61:442-450. http://dx.doi. org/10.1525/bio.2011.61.6.6

Hobbs, R. J., and D. A. Norton. 1996. Towards a conceptual framework for restoration ecology. Restoration Ecology 4:93110. http://dx.doi.org/10.1111/j.1526-100X.1996.tb00112.x

Icelandic Ministry for the Environment. 2007. Iceland's climate change strategy. Ministry for the Environment, Reykjavík, Iceland. [online] URL: http://eng.umhverfisraduneyti. is/media/PDF skrar/Stefnumorkun i loftslagsmalum enlokagerd. pdf

Jansson, R., C. Nilsson, and B. Malmqvist. 2007. Restoring freshwater ecosystems in riverine landscapes: the roles of connectivity and recovery processes. Freshwater Biology 52:589-596. http://dx.doi.org/10.1111/j.1365-2427.2007.01737. $\underline{x}$

Jeppesen, E., M. Meerhoff, B. A. Jacobsen, R. S. Hansen, M. Søndergaard, J. P. Jensen, T. L. Lauridsen, N. Mazzeo, and C. W. C. Branco. 2007. Restoration of shallow lakes by nutrient control and biomanipulation - the successful strategy varies with lake size and climate. Hydrobiologia 581:269-285. http://dx.doi.org/10.1007/s10750-006-0507-3

Jones, W., J. Eldridge, J. P. Silva, and N. Schiessler. 2007. LIFE and Europe's rivers. Protecting and improving our water resources. European Commission, Luxembourg. [online] URL: http://ec.europa.eu/environment/life/publications/ lifepublications/lifefocus/documents/rivers.pdf

Jörgensen, D., and B. Renöfält. 2013. Damned if you do, dammed if you don't: debates on dam removal in the Swedish media. Ecology and Society 18(1):18. http://dx.doi. org/10.5751/ES-05364-180118

Jungwirth, M., S. Muhar, and S. Schmutz. 2002. Reestablishing and assessing ecological integrity in riverine landscapes. Freshwater Biology 47:867-887. http://dx.doi. org/10.1046/j.1365-2427.2002.00914.x

Kristensen, E. A., A. Baattrup-Pedersen, and H. Thodsen. 2011. An evaluation of restoration practises in lowland 
streams: Has the physical integrity been re-created? Ecological Engineering 37:1654-1660. http://dx.doi.org/10.1016/ j.ecoleng.2011.06.043

Kuuluvainen, T., K. Aapala, P. Ahlroth, M. Kuusinen, T. Lindholm, T. Sallantaus, J. Siitonen, and H. Tukia. 2002. Principles of ecological restoration of boreal forested ecosystems: Finland as an example. Silva Fennica 36:409422.

Laine, A. M., M. Leppälä, O. Tarvainen, M. L. Päätalo, R. Seppänen, and A. Tolvanen. 2011. Restoration of managed pine fens: effect on hydrology and vegetation. Applied Vegetation Science 14:340-349. http://dx.doi.org/10.1111/ j.1654-109X.2011.01123.x

Larsen, J. B. 1995. Ecological stability of forests and sustainable silviculture. Forest Ecology and Management 73:85-96. http://dx.doi.org/10.1016/0378-1127(94)03501$\underline{\mathrm{m}}$

Larsen, J. B. 2012. Close-to-nature forest management: the Danish approach to sustainable forestry. In J. J. Diez, editor. Sustainable forest management-current research. [online] URL: http://www.intechopen.com/books/sustainable-forestmanagement-current-research/sustainable-forestry-through-closeto-nature-management

Larsen, J. B., and A. B. Nielsen. 2007. Nature-based forest management-Where are we going?: Elaborating forest development types in and with practice. Forest Ecology and Management 238:107-117. http://dx.doi.org/10.1016/j. foreco.2006.09.087

Lejon, A. G. C., B. M. Renofalt, and C. Nilsson. 2009. Conflicts associated with dam removal in Sweden. Ecology and Society 14(2):4. [online] URL: http://www. ecologyandsociety.org/vol14/iss2/art4/

Lilja, S., M. De Chantal, T. Kuuluvainen, I. Vanha-Majamaa, and P. Puttonen. 2005. Restoring natural characteristics in managed Norway spruce [Picea abies (L.) Karst.] stands with partial cutting, dead wood creation and fire: immediate treatment effects. Scandinavian Journal of Forest Research 20:68-78. http://dx.doi.org/10.1080/14004080510040977

Lindahl, T., and T. Söderqvist. 2004. Building a catchmentbased environmental programme: a stakeholder analysis of wetland creation in Scania, Sweden. Regional Environmental Change 4:132-144. http://dx.doi.org/10.1007/s10113-004-0072-0

Lindborg, R., and O. Eriksson. 2004. Effects of restoration on plant species richness and composition in Scandinavian seminatural grasslands. Restoration Ecology 12:318-326. http:// dx.doi.org/10.1111/j.1061-2971.2004.00334.x

Lindenmayer, D. B., K. B. Hulvey, R. J. Hobbs, M. Colyvan, A. Felton, H. Possingham, W. Steffen, K. Wilson, K.
Youngentob, and P. Gibbons. 2012. Avoiding bio-perversity from carbon sequestration solutions. Conservation Letters 5:28-36. http://dx.doi.org/10.1111/j.1755-263X.2011.00213. $\underline{\mathrm{X}}$

Lü, Y. H., B. J. Fu, W. Wei, X. B. Yu, and R. H. Sun. 2011. Major ecosystems in China: dynamics and challenges for sustainable management. Environmental Management 48:1327. http://dx.doi.org/10.1007/s00267-011-9684-6

Mabry, C. M., L. A. Brudvig, and R. C. Atwell. 2010. The confluence of landscape context and site-level management in determining Midwestern savanna and woodland breeding bird communities. Forest Ecology and Management 260:4251. http://dx.doi.org/10.1016/j.foreco.2010.03.028

Madgwick, F. J., and A. T. Jones. 2002. Europe. Pages 32-56 in M. R. Perrow and A. J. Davy, editors. Handbook of Ecological Restoration. Volume 2. Restoration in Practice. Cambridge University Press, Cambridge, UK.

Madsen, P., F. A. Jensen, and S. Fodgaard. 2005. Afforestation in Denmark. Pages 211-224 in J. A. Stanturf and P. Madsen, editors. Restoration of boreal and temperate forests. CRC Press, Boca Raton, Florida, USA.

Magnusson, B. 2010. NOBANIS_invasive alien species fact sheet-Lupinus nootkatensis. Page 11. [online] URL: http:// www.nobanis.org/files/factsheets/Lupinus nootkatensis.pdf

Magnússon, S. H. 1997. Restoration of eroded areas in Iceland. Pages 188-211 in K. M. Urbanska, N. R. Webb, and P. J. Edwards, editors. Restoration ecology and sustainable development. Cambridge Univeristy Press, Cambridge, UK.

Mälson, K., I. Backéus, and H. Rydin. 2008. Long-term effects of drainage and initial effects of hydrological restoration on rich fen vegetation. Applied Vegetation Science 11:99-106. http://dx.doi.org/10.1111/j.1654-109X.2008.tb00208.x

Martinsen, O.-E., and D. Hagen. 2010. Tilbakeføring av Hjerkinn skytefelt til sivile formål (Hjerkinn PRO) [Restoration of Hjerkinn firing range into nature conservation areas (Hjerkinn PRO)]. Pages 35-37 in D. Hagen and A. B. Skrindo, editors. Restaurering av natur i Norge-et innblikk $i$ fagfeltet, fagmiljøet og pågående aktivitet [Restoration of nature in Norway-a glimpse into the tematic field, professional institutions and ongoing activity]. Norwegian Institute for Nature Research, Trondheim, Norway. NINA Temahefte 42.

Martinsen, O.-E., and T. V. Vedum. 2010. Restaurering av 150 dammer i kulturlandskapet på Hedmarken. [Restoration of 150 ponds in the cultural landscape at Hedmarken, Norway]. Pages 94-95 in D. Hagen and A. B. Skrindo, editors. Restaurering av natur $i$ Norge-et innblikk $i$ fagfeltet, fagmiljøet og pågående aktivitet [Restoration of nature in Norway-a glimpse into the tematic field, professional 
institutions and ongoing activity]. Norwegian Institute for Nature Research, Trondheim, Norway. NINA Temahefte 42.

McGhee, W., J. Craig, R. de Groot, J. S. Miller, and K. Bowers. 2007. Making restoration work: nonmonetary mechanisms. Pages 294-302 in J. Aronson, S. J. Milton, and J. N. Blignaut, editors. Restoring natural capital. Science, business, and practice. Island Press, Washington, D.C., USA.

METSO. 2008. Government resolution on the forest biodiversity programme for Southern Finland 2008-2016. Ministry of the Environment and Ministry of Agriculture and Forestry, Finland, Helsinki, Finland.

Milgrom, T. 2008. Environmental aspects of rehabilitating abandoned quarries: Israel as a case study. Landscape and Urban Planning 87:172-179. http://dx.doi.org/10.1016/j. landurbplan.2008.06.007

Millennium Ecosystem Assessment (MEA). 2005. Ecosystems and human well-being: biodiversity synthesis. World Resources Institute, Washington, D.C., USA.

Ministry of Agriculture. 2011. Proposal for the national strategy concerning the responsible and sustainable use of mires and peatlands. Ministry of Agriculture, Helsinki, Finland. [online] URL: http://www.mmm.fi/attachments/ ymparisto/suojaturvemaat/5wXEXk8I7/Suostrategia nettiin. pdf

Moen, A. 1999. Vegetation. Norwegian Mapping Authority, Hønefoss, Norway.

Morsing, J., S. I. Frandsen, H. Vejre, and K. RaulundRasmussen. 2013. Do the principles of ecological restoration cover EU LIFE Nature cofunded projects in Denmark? Ecology and Society 18(4): 15. http://dx.doi.org/10.5751/ ES-05847-180415

Navrud, S. 2001. Economic valuation of inland recreational fisheries: empirical studies and their policy use in Norway. Fisheries Management and Ecology 8:369-382. http://dx.doi. org/10.1111/j.1365-2400.2001.00267.x

Nielsen, A., D. Trolle, M. Søndergaard, T. L. Lauridsen, R. Bjerring, J. E. Olesen, and E. Jeppesen. 2012. Watershed land use effects on lake water quality in Denmark. Ecological Applications 22:1187-1200. http://dx.doi.org/10.1890/11-1831.1

Nilsson, C., R. Jansson, E. C. H. Keskitalo, T. Vlassova, M. L. Sutinen, J. Moen, and F. S. Chapin, III. 2010. Challenges to adaptation in northernmost Europe as a result of global climate change. Ambio 39:81-84. http://dx.doi.org/10.1007/ s13280-009-0010-y

Nilsson, C., F. Lepori, B. Malmqvist, E. Törnlund, N. Hjerdt, J. M. Helfield, D. Palm, J. Östergren, R. Jansson, E. Brännäs, and H. Lundqvist. 2005. Forecasting environmental responses to restoration of rivers used as $\log$ floatways: an interdisciplinary challenge. Ecosystems 8:779-800. http://dx. doi.org/10.1007/s10021-005-0030-9

Nord-Larsen, T., A. Bastrup-Birk, I. M. Thomsen, B. B. Jørgensen, and V. K. Johannsen. 2010. Skove \& plantager 2009. Forest \& Landscape, University of Copenhagen, Copenhagen, Denmark.

Norderhaug, A., and L. Johansen. 2011. Kulturmark og boreal hei [Semi-natural sites and cultural heath]. In A. Lindgaard and S. Henriksen. The 2011 Norwegian Red List for ecosystems and habitat types. Norwegian Biodiversity Information Centre, Trondheim, Norway.

Nordic Council of Ministers. 2008. Environmental Action Plan 2009-2012. Nordic Council of Ministers, Copenhagen, Denmark. [online] URL: http://www.norden.lv/data/Environm Action. pdf

Nørring, N. P., and E. Jørgensen. 2009. Eutrophication and agriculture in Denmark: 20 years of experience and prospects for the future. Hydrobiologia 629:65-70. http://dx.doi. org/10.1007/s10750-009-9772-2

Olsson, E. G. A., G. Austrheim, and S. N. Grenne. 2000. Landscape change patterns in mountains, land use and environmental diversity, Mid-Norway 1960-1993. Landscape Ecology 15:155-170. http://dx.doi.org/10.1023/a:1008173628016

Óskarsson, H. 1998. Framræsla votlendis á Vesturlandi [Drainage of wetlands in West Iceland]. Pages 121-129 in J. S. Ólafsson, editor. Íslensk votlendi: verndun og nýting [Wetlands in Iceland: protection and utilization]. Háskólaútgáfan, Reykjavík, Iceland.

Oskarsson, H., A. Sigurgeirsson, and K. Raulund-Rasmussen. 2006. Survival, growth, and nutrition of tree seedlings fertilized at planting on Andisol soils in Iceland: six-year results. Forest Ecology and Management 229:88-97. http:// dx.doi.org/10.1016/j.foreco.2006.03.018

Øyen, B. H. 1999. Buskfuru og bergfuru-en historie fra kystskogbruket i Norge. [Mountain pine and dwarf mountain pine-a history from the coastal forestry in Norway]. Blyttia $57: 162-170$.

Pedersen, M. L., J. M. Andersen, K. Nielsen, and M. Linnemann. 2007. Restoration of Skjern River and its valley: project description and general ecological changes in the project area. Ecological Engineering 30:131-144. http://dx. doi.org/10.1016/j.ecoleng.2006.06.009

Pétursdóttir. 2011. Bændur græða landið - samstarf um uppgræðslu og endurheimt vistkerfa [Farmers Heal the Land - a cooperation on revegetation and restoration]. Pages 84 85 in Á. L. Aradóttir and G. Halldórsson, editors. Vistheimt á Íslandi [Restoration in Iceland]. Agricultural University of Iceland and Soil Conservation Service of Iceland, Reykjavík, Iceland. 
Prober, S. M., K. R. Thiele, I. D. Lunt, and T. B. Koen. 2005. Restoring ecological function in temperate grassy woodlands: manipulating soil nutrients, exotic annuals and native perennial grasses through carbon supplements and spring burns. Journal of Applied Ecology 42:1073-1085. http://dx. doi.org/10.1111/j.1365-2664.2005.01095.x

Raatikainen, K., editor 2009. Perinnebiotooppien seurantaohje (in Finnish with Swedish summary; Uppföljningsanvisning för vårdbiotoper). Nature Protection Publications of Metsähallitus, Helsinki, Finland, Series B 117.

Rassi, P., E. Hyvärinen, A. Juslen, and I. Mannerkoski, editors. 2010. Red List of Finnish species. Ympäristöministeriö \& Suomen Ympäristökeskus, Helsinki, Finland.

Roberge, J. M., G. Mikusinski, and S. Svensson. 2008. The White-backed Woodpecker: umbrella species for forest conservation planning? Biodiversity and Conservation 17:2479-2494. http://dx.doi.org/10.1007/s10531-008-9394-4

Rydgren, K., R. Halvorsen, A. Odland, and G. Skjerdal. 2011. Restoration of alpine spoil heaps: successional rates predict vegetation recovery in 50 years. Ecological Engineering 37:294-301. http://dx.doi.org/10.1016/j.ecoleng.2010.11.022

Schuyt, K. 2005. Perverse policy incentives. Pages $78-83$ in S. Mansourian, D. Vallauri, N. Dudley, and I. C. W. W. International, editors. Forest restoration in landscapes. Beyond planting trees. Springer, New York, USA.

Silva, J. P., L. Phillips, W. Jones, J. Eldridge, and E. O`Hara. 2007. LIFE and Europe's wetlands. Restoring a vital ecosystem. European Commission, Luxembourg. [online] URL: http://ec.europa.eu/environment/life/publications/ lifepublications/lifefocus/documents/wetlands.pdf

Similä, M., and K. Junninen, editors. 2011. Guide for forest habitat restoration and management (in Finnish with English summary). Nature Protection Publications of Metsähallitus, Helsinki, Finland, Series B 157.

Skarphéðinsson, K. H. 2011. Restoration of the Icelandic Sea Eagle population. Pages 18-21 in G. Halldórsson, editor. Restoring the North-challenges and opportunities. International Restoration Conference, October 20-22, 2011. Selfoss, Iceland. Soil Conservation Service of Iceland and Agricultural University of Iceland, Reykjavík, Iceland. [online] URL: http://www.reno.is/lisalib/getfile.aspx?itemid=5040

Statistics Norway. 2012. [online] URL: http://www. miljostatus.no/Tema/Naturmangfold/Arealbruk/

Statistics Sweden. 2009. Land use in Sweden. Fifth edition. SCB-Tryck, Örebro. [online] URL: http://www.scb.se/ statistik/ publikationer/MI0803 2005A01 BR MI03BR0801. pdf
Steffens, W. 2008. Significance of aquaculture for the conservation and restoration of sturgeon populations. Bulgarian Journal of Agricultural Science 14:155-164. [online] URL: http://www.agrojournal.org/14/02-08-08.pdf

Suding, K. N. 2011. Toward an era of restoration in ecology: successes, failures, and opportunities ahead. Annual Review of Ecology, Evolution, and Systematics 42:465-487. http://dx. doi.org/10.1146/annurev-ecolsys-102710-145115

Sverdrup-Thygeson, A., and T. Birkemoe. 2009. What window traps can tell us: effect of placement, forest openness and beetle reproduction in retention trees. Journal of Insect Conservation 13:183-191. http://dx.doi.org/10.1007/ $\underline{\text { s10841-008-9141-X }}$

Taugbøl, T., O. I. Vistad, C. Nellemann, B. P. Kaltenborn, A.C. Flyen, B. C. Horgen, R. Grefsrud, K. Lein, J. B. Sivertsen, and K. Gurigard. 2001. Construction of recreational homes in Norway. A summary and evaluation of different environmental and social effects of constructing recreational homes in the mountainous andforested areas in southern Norway. Rep. No. NINA Oppdragsmelding 709. NINA, Lillehammer.

Tuhkanen, S. 1987. The phytogeographical position of the Faroe Islands and their ecoclimatic correspondences on the other continents-problems associated with highly oceanic areas. Annales Botanici Fennici 24:111-135.

Walker, L. R., and R. del Moral. 2003. Primary succession and ecosystem rehabilitation. Cambridge University Press. http://dx.doi.org/10.1017/CBO9780511615078

Walker, L. R., and R. del Moral. 2009. Transition dynamics in succession: implications for rates, trajectories, and restoration. Pages 33-49 in R. J. Hobbs and K. N. Suding, editors. New Models for Ecosystem Dynamics and Restoration. Island Press, Washington, D.C., USA.

Webb, N. R. 1998. The traditional management of European heathlands. Journal of Applied Ecology 35:987-990. http:// dx.doi.org/10.1111/j.1365-2664.1998.tb00020.x 